\title{
Smoking-Related DNA Methylation is Differentially Associated with Cadmium Concentration in Blood
}

\author{
Jae-Eun Lee ${ }^{1}$ (D) $\cdot$ Hye-Ryun Kim ${ }^{1}$ (D) $\cdot$ Mee-hee Lee ${ }^{1}$ (D) Nam-Hee Kim ${ }^{1}$ (D) \\ Kyoung-Min Wang ${ }^{1} \mathbb{D} \cdot$ Sang-hyeop Lee ${ }^{1} \mathbb{D} \cdot$ Ok Park $^{1} \cdot$ Eun-Jung Hong ${ }^{1} \mathbb{D}$. \\ Jong-Woo Youn ${ }^{1} \cdot$ Young-Youl Kim ${ }^{1}$ (D)
}

Received: 16 September 2019 / Accepted: 17 April 2020 / Published online: 28 April 2020

(c) The Author(s) 2020

\begin{abstract}
Tobacco smoking, a risk factor for several human diseases, can lead to alterations in DNA methylation. Smoking is a key source of cadmium exposure; however, there are limited studies examining DNA methylation alterations following smoking-related cadmium exposure. To identify such cadmium exposure-related DNA methylation, we performed genome-wide DNA methylation profiling using DNA samples from 50 smokers and 50 non-smokers. We found that a total of $136 \mathrm{CpG}$ sites (including 70 unique genes) were significantly differentially methylated in smokers as compared to that in non-smokers. The CpG site $\operatorname{cg} 05575921$ in the AHRR gene was hypomethylated $(\Delta B>-0.2)$ in smokers, which was in accordance with previous studies. The rs951295 (within RNA gene LOC105370802) and cg00587941 sites were under-methylated by $>15 \%$ in smokers, whereas cg11314779 (within CELFO) and cg02126896 were over-methylated by $\geq 15 \%$. We analyzed the association between blood cadmium concentration and DNA methylation level for 50 smokers and 50 non-smokers. DNA methylation rates of $307 \mathrm{CpG}$ sites (including 207 unique genes) were significantly correlated to blood cadmium concentration (linear regression $P$ value $<0.001$ ). The four significant loci (cg05575921 and $\operatorname{cg} 23576855$ in AHRR, cg03636183 in F2RL3, and $\operatorname{cg} 21566642$ ) were under-methylated by $>10 \%$ in smokers compared to that in non-smokers. In conclusion, our study demonstrated that DNA methylation levels of rs951295, cg00587941, cg11314779, and cg02126896 sites may be new putative indicators of smoking status. Furthermore, we showed that these four loci may be differentially methylated by cadmium exposure due to smoking.
\end{abstract}

Electronic Supplementary Material The online version of this article (https://doi.org/10.1007/s1052 8-020-09965-y) contains supplementary material, which is available to authorized users.

Young-Youl Kim

youngyk@nih.go.kr

1 Division of Biobank for Health Sciences, Center for Genome Science, Korea National Institute of Health, Korea Centers for Disease Control and Prevention, Cheongju, Korea 
Keywords Cadmium exposure $\cdot$ DNA methylation $\cdot$ Smoker $\cdot$ Smoking

\section{Introduction}

Tobacco smoking is a risk factor for various diseases such as cancers, pulmonary and cardiovascular disease, type-2 diabetes, and obesity (Vineis et al. 2004; Mathers and Loncar 2006, Thun et al. 2010, CDC 2008). The World Health Organization (WHO) reported that about 6 million people worldwide die from smoking annually (WHO 2014). Smoking is the primary cause of approximately half-a-million deaths annually in the United States (Mokdad et al. 2004), and of most lung cancer cases (more than 4 of 5 cases) in developed countries (Fairley et al. 2010). Notably, smoking is a main source of cadmium exposure; cadmium accumulates gradually in the human body and has a half-life of 10-30 years (Jarup and Akesson 2009). Cadmium concentrations are much higher in the blood samples of smokers than that in non-smokers (Batariova et al. 2006; El-Agha and Gokmen 2002; Elinder et al. 1983), and smoking-induced increase in urinary cadmium concentration is associated with kidney dysfunction (Mortensen et al. 2011). Cadmium exposure is associated with the development or progression of cancers, cardiovascular dysfunction, nephrotoxicity, and bone damage (Larsson and Wolk 2016; Nordberg et al. 1992; Jarup and Akesson 2009).

Smoking can cause changes in DNA methylation, which plays an essential role in the transcriptional regulation of oncogenes, tumor suppressor genes, and inflammationrelated genes (Sundar et al. 2011; Yao and Rahman 2011). Generally, hypermethylation at specific $\mathrm{CpG}$ sites in the gene promoter is associated with gene silencing and hypomethylation is related to the activation of gene expression (Yang and Schwartz 2011; Jones 2012). Variation in DNA methylation at specific CpG sites is associated with diseases such as cancers, inflammatory, and pulmonary diseases (Sundar et al. 2011, 2013; Selamat et al. 2012; Morrow et al. 2016; Cheng et al. 2016). Recently, several studies have investigated the changes in DNA methylation associated with smoking, as well as the link between smoking and diseases, such as lung cancer and chronic obstructive pulmonary disease, with respect to DNA methylation status ( $\mathrm{Ma}$ and Li 2017; Sundar et al. 2017). Cadmium exposure due to smoking can induce alterations in DNA methylation (Virani et al. 2016); however, there are a limited number of studies focused on alterations in DNA methylation due to smoking-related cadmium exposure. In this study, we identified differentially methylated $\mathrm{CpG}$ sites in Korean smokers compared to Korean non-smokers, through a microarray-based approach. Further, we also investigated whether these CpG sites were differentially methylated by cadmium exposure due to smoking.

\section{Methods and Materials}

\section{Study Population}

Study participants included 100 non-smokers and 100 current smokers, who enrolled as volunteers for the fifth Korean National Health and Nutrition 
Examination Survey (2008-2011). We randomly selected subjects based on sex, age, and self-reported smoking history. All selected subjects were male and there was no difference in the average age of the two groups; the average age of the non-smokers was 52 years and that of smokers was 51 years (Table 1). Non-smokers had no smoking history over their lifetime. Smokers had a smoking history of more than 20 cigarettes per day for the past 20 years and first started smoking after the age of 15; the average smoking period per person was 31.54 years and the annual average number of packs of cigarettes per person was 439.64. All study participants provided informed consent.

\section{DNA Methylation Analyses}

A total of 50 non-smokers and 50 smokers were randomly selected from participants enrolled in the study for DNA methylation analyses. DNA samples, extracted from buffy coat samples of these subjects, were obtained from the National Biobank of Korea. DNA was bisulfite-converted using EZ DNA Methylation ${ }^{\mathrm{TM}}$ Kit (Zymoresearch, California, USA) and DNA methylation profiles were analyzed using the Infinium Human Methylation $450 \mathrm{~K}$ BeadChip (Illumina, San Diego, CA), which contains 485,512 CpG sites, according to the manufacturer's protocol. The methylation rate at each $\mathrm{CpG}$ site was calculated by comparing fluorescent signals from methylated and unmethylated sites. The methylation rates are presented as mean beta (ß) values, which ranged from 0 (at a completely unmethylated site) to 1.0 (at a completely methylated site). Delta $(\Delta) \beta$ value is defined as the difference between the mean $\beta$ value of smokers and that of non-smokers (mean $\beta$ value of smokers - mean $\beta$ value of non-smokers). Methylation rates between the two groups were compared using the independent $t$ test statistical method. $\mathrm{CpG}$ sites with $\mid \Delta \beta$ valuel $\geq 0.05$ and $P$ value $<0.01$ were considered as differentially methylated.

\section{Measurement of Urinary Cotinine and Blood Cadmium Levels}

Urinary cotinine concentrations were measured by Gas Chromatography Mass Spectrometry (GCMS) using Perkin Elmer Clarus 600 T (PerkinElmer, Finland). Blood

Table 1 Characteristics of study subjects

\begin{tabular}{lll}
\hline Variables & Non-smokers $(n=100)$ & Smokers $(n=100)$ \\
\hline Age, average (SD) & $51.89(9.23)$ & $51.40(8.32)$ \\
Concentration $(\mu \mathrm{g} / \mathrm{L})$ of blood cadmium $(\mathrm{SD})$ & $0.83(4.23)$ & $1.67(0.68)$ \\
Concentration $(\mathrm{ng} / \mathrm{ml})$ of urine cotinine (SD) & $12.22(17.16)$ & $1847.95(1178.87)$ \\
Cigarettes per day, average (SD) & - & $24.09(7.77)$ \\
Total amount of smoking per person, packs (SD) & - & $439.64(141.75)$ \\
Smoking years per person, average (SD) & - & $31.54(8.42)$ \\
\hline
\end{tabular}


cadmium concentrations were measured by Graphite Furnace Atomic Absorption Spectrometry (GFAAS) using PerkinElmer AAnalyst 600 (PerkinElmer, Finland).

\section{Gene Ontology Analyses}

To identify the biological functions of genes that are differentially methylated due to smoking or cadmium exposure, Gene Ontology (biological process terms) analysis was performed using the DAVID Bioinformatics Resources 6.8 Functional Annotation Tool (https://david.ncifcrf.gov/). For this analysis, we used genes differentially methylated by smoking or cadmium exposure. Significant terms were chosen when the Benjamini-Hochberg-corrected $P$ value $<0.05$.

\section{Correlation Analyses}

The correlation between blood cadmium concentrations and DNA methylation rates was assessed using a linear regression statistical method. For this analysis, the methylation rate $(ß$ value) at each $\mathrm{CpG}$ site and blood cadmium concentration $(\mu \mathrm{g} / \mathrm{L})$ from 50 non-smokers and 50 smokers was used. $P$ value $<0.001$ was considered statistically significant.

\section{Results}

\section{Comparison of Blood Cadmium and Urinary Cotinine Levels Between Smokers and Non-smokers}

The smokers $(n=100)$ and non-smokers $(n=100)$ had mean blood cadmium concentration of $1.67 \pm 0.68 \mu \mathrm{g} / \mathrm{L}$ and $0.83 \pm 4.23 \mu \mathrm{g} / \mathrm{L}$, respectively (Table 1 ). The average concentration of blood cadmium was over 2 times higher in smokers compared to that in non-smokers. The urinary cotinine level is a sensitive biomarker for tobacco smoking (Kulza et al. 2012; Raja et al. 2016). Our results showed that the smokers and non-smokers had mean urinary cotinine concentration of $1847.95 \pm 1178.87 \mathrm{ng} /$ $\mathrm{mL}$ and $12.22 \pm 17.16 \mathrm{ng} / \mathrm{mL}$, respectively. The average concentration of urinary cotinine was over 100 times higher in smokers as compared to that in non-smokers.

\section{Differential DNA Methylation Between Smokers and Non-smokers}

A total of $136 \mathrm{CpG}$ sites, including 70 unique genes, were differentially methylated in smokers compared to non-smokers $(\mid \Delta B$ valuel $\geq 0.05 ; P$ value $<0.01)$ (Supplementary data 1). Among these, $92 \mathrm{CpG}$ sites, including 51 unique genes, showed under-methylation in smokers compared to non-smokers; $44 \mathrm{CpG}$ sites, including 19 unique genes, exhibited over-methylation in smokers. The average $\Delta B$ value of the 92 under-methylated $\mathrm{CpG}$ sites was 0.07 (ranged from -0.05 to -0.21 ), and the average $\Delta \beta$ value of the 44 over-methylated $\mathrm{CpG}$ sites was 0.07 (ranged from 0.05 to 0.15 ). The top 30 sites with the highest fold change 
among differentially methylated $\mathrm{CpG}$ sites are listed in Table 2. We found 25 under-methylated $\mathrm{CpG}$ sites and 5 over-methylated $\mathrm{CpG}$ sites in smokers. The $\operatorname{cg} 05575921$ site in $A H R R$ showed hypomethylation $[\Delta B$ value $=-0.21$; $\log _{2}$ (fold change $\left.)=-0.41\right]$. The rs951295 in RNA gene LOC105370802 $[\Delta \beta$ value $=-0.18 ; \log _{2}($ fold change $\left.)=-0.62\right], \operatorname{cg} 00587941[\Delta \beta$ value $=-0.16 ;$ $\log _{2}$ (fold change $\left.)=-0.31\right]$, and $\operatorname{cg} 23576855$ in $A H R R\left[\Delta \beta\right.$ value $=-0.17 ; \log _{2}$ (fold change $)=-0.40$ ] were under-methylated, while cg11314779 in CELE6 [ $\Delta$ $ß$ value $=0.15 ; \log _{2}($ fold change $\left.)=0.38\right]$ and $\operatorname{cg} 02126896\left[\Delta ß\right.$ value $=0.15 ; \log _{2}$ $($ fold change $)=0.39$ ] were over-methylated.

Table 2 Top 30 differentially methylated CpG sites in non-smokers $(n=50)$ and smokers $(n=50)$

\begin{tabular}{|c|c|c|c|c|c|c|}
\hline Probe ID & Gene symbol & $\begin{array}{l}\beta \text { value of } \\
\text { non-smokers }\end{array}$ & $\begin{array}{l}\beta \text { value of } \\
\text { smokers }\end{array}$ & $\Delta \beta$ value & $\begin{array}{l}t \text { test } \\
P \text { value }\end{array}$ & $\log _{2}$ (fold change) ${ }^{\mathrm{a}}$ \\
\hline rs951295 & LOC105370802 & 0.51 & 0.33 & -0.18 & 0.002 & -0.62 \\
\hline $\operatorname{cg} 02249911$ & CASP3;CCDC111 & 0.24 & 0.17 & -0.07 & 0.005 & -0.52 \\
\hline $\operatorname{cg} 06644428$ & & 0.19 & 0.13 & -0.06 & $<0.001$ & -0.51 \\
\hline $\operatorname{cg} 20059012$ & RARG & 0.18 & 0.13 & -0.05 & $<0.001$ & -0.51 \\
\hline $\operatorname{cg} 25538415$ & DCAKD & 0.24 & 0.17 & -0.07 & 0.006 & -0.47 \\
\hline $\operatorname{cg} 26374206$ & ZNF709 & 0.18 & 0.14 & -0.05 & $<0.001$ & -0.43 \\
\hline $\operatorname{cg} 00909514$ & C1orf106 & 0.21 & 0.15 & -0.05 & $<0.001$ & -0.43 \\
\hline $\operatorname{cg} 05575921$ & AHRR & 0.83 & 0.62 & -0.21 & $<0.001$ & -0.41 \\
\hline $\operatorname{cg} 23576855$ & AHRR & 0.71 & 0.54 & -0.17 & $<0.001$ & -0.40 \\
\hline $\operatorname{cg} 19211853$ & RBM26 & 0.26 & 0.20 & -0.06 & $<0.001$ & -0.40 \\
\hline $\operatorname{cg} 21566642$ & & 0.52 & 0.41 & -0.12 & $<0.001$ & -0.37 \\
\hline $\operatorname{cg} 07339236$ & ATP9A & 0.23 & 0.18 & -0.05 & $<0.001$ & -0.37 \\
\hline $\operatorname{cg} 14743534$ & RASA4CP;FLJ35390 & 0.22 & 0.17 & -0.05 & 0.004 & -0.36 \\
\hline $\operatorname{cg} 09682128$ & & 0.22 & 0.17 & -0.05 & 0.006 & -0.34 \\
\hline $\operatorname{cg} 17246140$ & HAAO & 0.22 & 0.17 & -0.05 & $<0.001$ & -0.34 \\
\hline $\operatorname{cg} 14817490$ & AHRR & 0.32 & 0.26 & -0.07 & $<0.001$ & -0.33 \\
\hline $\operatorname{cg} 19980771$ & SLC22A16 & 0.33 & 0.26 & -0.07 & 0.006 & -0.33 \\
\hline $\operatorname{cg} 12075498$ & JAK1 & 0.31 & 0.25 & -0.06 & 0.002 & -0.33 \\
\hline $\operatorname{cg} 05951221$ & & 0.43 & 0.34 & -0.08 & $<0.001$ & -0.31 \\
\hline $\operatorname{cg} 19080354$ & ATHL1 & 0.40 & 0.32 & -0.08 & 0.008 & -0.31 \\
\hline cg21974656 & & 0.39 & 0.32 & -0.08 & 0.002 & -0.31 \\
\hline $\operatorname{cg} 00587941$ & & 0.85 & 0.69 & -0.16 & 0.001 & -0.31 \\
\hline $\operatorname{cg} 17759274$ & LGALS7 & 0.30 & 0.24 & -0.06 & 0.005 & -0.30 \\
\hline $\operatorname{cg} 12339131$ & & 0.71 & 0.58 & -0.13 & 0.003 & -0.30 \\
\hline $\operatorname{cg} 25327888$ & CACNB2 & 0.25 & 0.20 & -0.05 & 0.005 & -0.29 \\
\hline $\operatorname{cg} 11314779$ & CELF6 & 0.50 & 0.65 & 0.15 & 0.005 & 0.38 \\
\hline $\operatorname{cg} 02126896$ & & 0.48 & 0.63 & 0.15 & 0.006 & 0.39 \\
\hline $\operatorname{cg} 01134012$ & GSDMD & 0.13 & 0.18 & 0.05 & 0.002 & 0.52 \\
\hline $\operatorname{cg} 14721632$ & GSDMD & 0.14 & 0.23 & 0.08 & 0.007 & 0.66 \\
\hline $\operatorname{cg} 05419812$ & & 0.11 & 0.18 & 0.07 & 0.005 & 0.68 \\
\hline
\end{tabular}

${ }^{\mathrm{a}} \log _{2}$ ( $\beta$ value of smokers/ $\beta$ value of non - smokers $)$ 
We performed gene ontology analysis on 70 genes that were differentially methylated in smokers (Table 3). AHRR (cg05575921, cg23576855, cg14817490, cg03991871, cg21161138, cg25648203), GFII (cg09935388), HOPX (cg25456368), RARA (cg19572487), RARG (cg20059012), REST (cg25313468), and ZFP57 (cg12463578) are associated with negative regulation of transcription, and all were under-methylated in smokers.

\section{DNA Methylation Associated with Cadmium Exposure}

To identify cadmium exposure-related DNA methylation, we evaluated the correlation between blood cadmium concentration and DNA methylation rate at each CpG site, using genome-wide DNA methylation data obtained from 50 smokers and 50 non-smokers. The results showed that DNA methylation rates at $307 \mathrm{CpG}$ sites, including 207 unique genes, were significantly correlated to the blood cadmium concentrations of the study subjects $(P$ value $<0.001)$ (data not shown). The top ten sites with the most significant correlations were $\operatorname{cg} 03991871, \operatorname{cg} 05575921$, cg12806681, cg21161138, and cg23576855 in AHRR, cg03636183 in F2RL3, cg05951221, cg01940273, cg19859270 in GPR15, and cg21566642. We analyzed the biological functions of 207 genes (Table 4); these genes, including AHRR, $F 2 R L 3, H O P X, R A R A$, and $R A R B$, were found to be typically associated with transcription regulation and signal transduction.

\section{Identification of Genes Commonly Associated with Smoking and Blood Cadmium Exposure}

To identify DNA methylation induced by cadmium exposure due to smoking, we selected $\mathrm{CpG}$ sites that were differentially methylated in smokers from among the cadmium exposure-associated DNA methylation described above. Thirty-eight CpG sites (including 23 unique genes) were identified (Table 5). The cg05575921 and $\operatorname{cg} 23576855$ in $A H R R, \operatorname{cg} 03636183$ in F2RL3, and $\operatorname{cg} 21566642$, showed a $\Delta B$ value $<-1.0$ for DNA methylation rates between smokers and non-smokers.

\section{Discussion}

In this study, we identified smoking-induced methylation alterations at $136 \mathrm{CpG}$ sites (including 70 unique genes). The cg05575921 site in AHRR showed hypomethylation in smokers, in accordance with previous studies (Zeilinger et al. 2013; Dogan et al. 2014; Lee et al. 2017). These data support the suggestion that methylation levels of AHRR ( $\operatorname{cg} 05575921)$ may be used as an indicator of smoking intensity (Beach et al. 2015). Our findings were consistent with those of previous studies on smoking-associated DNA methylation at other $\mathrm{CpG}$ sites as well. Studies have reported that cg21161138 and cg26703534 in AHRR, cg01940273, cg06126421, cg21566642 (Zeilinger et al. 2013; Dogan et al. 2014), cg03636183 in F2RL3 (Zeilinger et al. 2013; Breitling et al. 2011), and $\operatorname{cg} 19572487$ in RARA (Zeilinger et al. 2013) are 


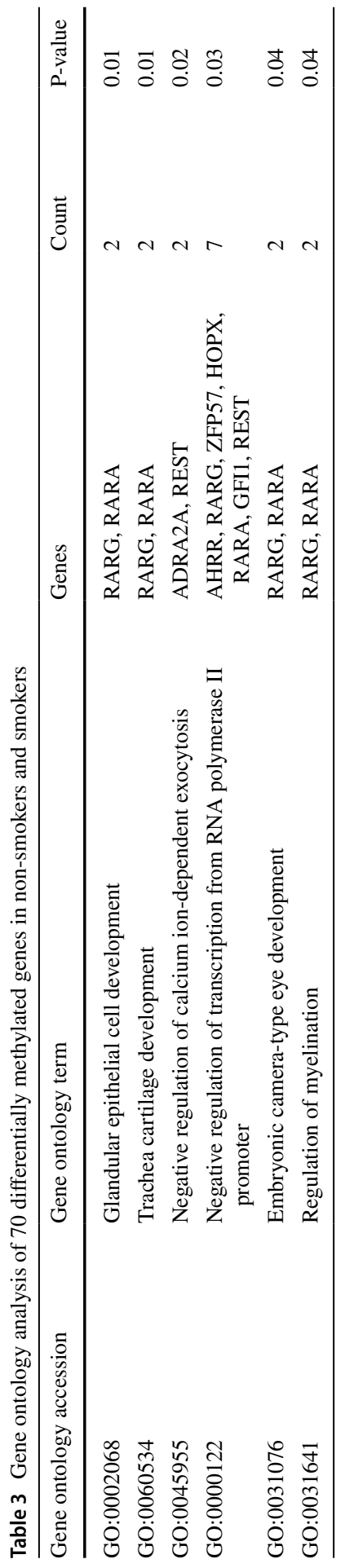




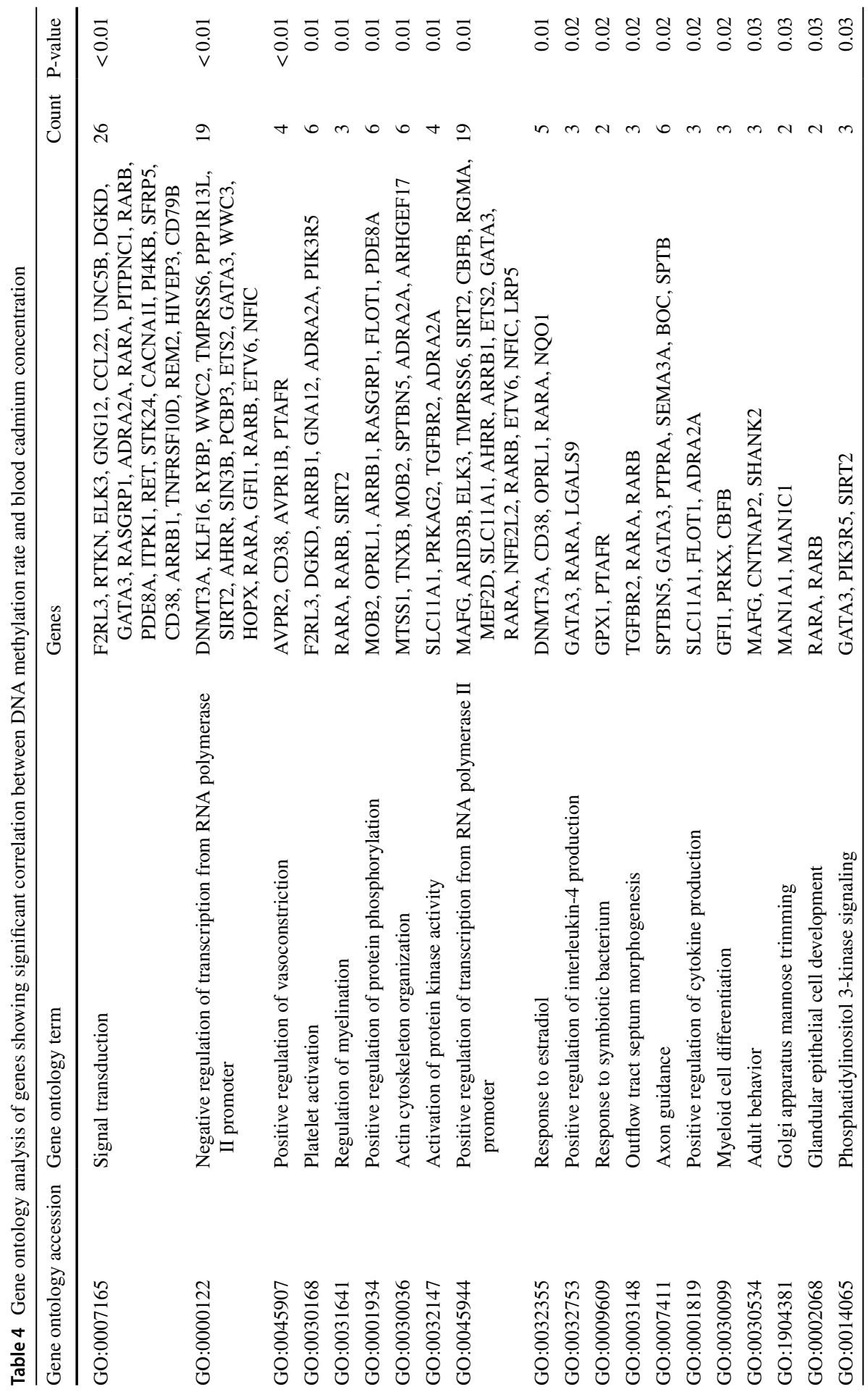




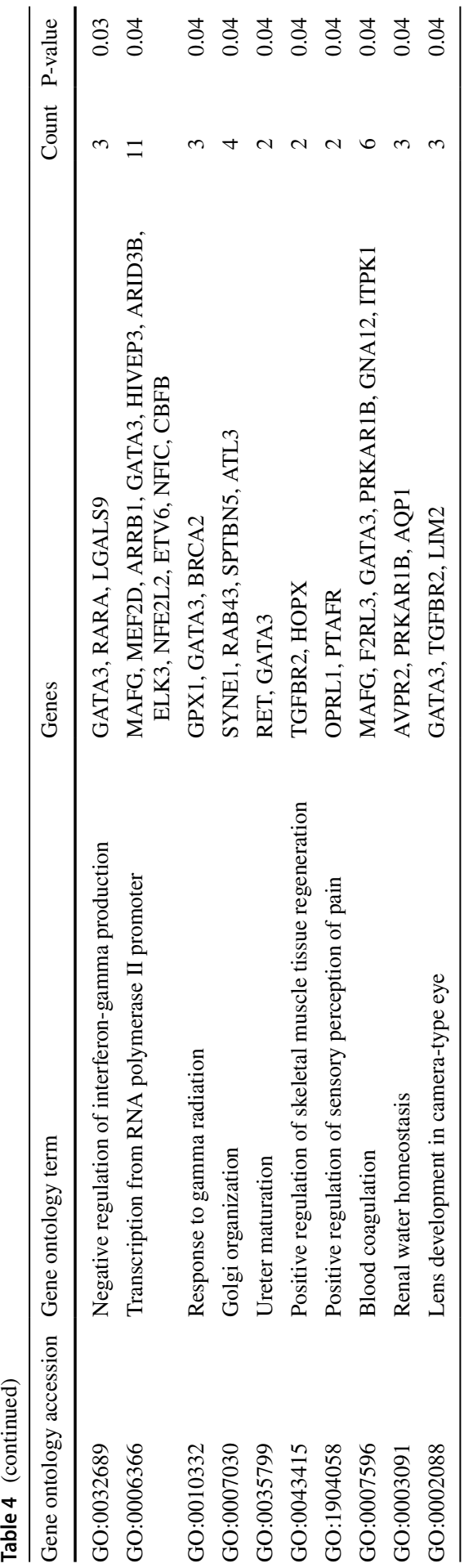


Table 5 Thirty-eight CpG sites that were differentially methylated due to smoking and blood cadmium concentration

\begin{tabular}{|c|c|c|c|c|c|c|}
\hline Probe & Gene symbol & $\begin{array}{l}\beta \text { value of } \\
\text { non-smokers }\end{array}$ & $\begin{array}{l}\beta \text { value of } \\
\text { smokers }\end{array}$ & $\Delta \beta$ value & $\begin{array}{l}t \text { test } \\
\mathrm{P} \text { value }\end{array}$ & $\log _{2}(\text { fold change })^{\mathrm{a}}$ \\
\hline cg06644428 & & 0.19 & 0.13 & -0.06 & $<0.001$ & -0.51 \\
\hline cg00909514 & C1orf106 & 0.21 & 0.15 & -0.05 & $<0.001$ & -0.43 \\
\hline $\operatorname{cg} 05575921$ & AHRR & 0.83 & 0.62 & -0.21 & $<0.001$ & -0.41 \\
\hline $\operatorname{cg} 23576855$ & AHRR & 0.71 & 0.54 & -0.17 & $<0.001$ & -0.40 \\
\hline cg19211853 & RBM26 & 0.26 & 0.20 & -0.06 & $<0.001$ & -0.40 \\
\hline $\operatorname{cg} 21566642$ & & 0.52 & 0.41 & -0.12 & $<0.001$ & -0.37 \\
\hline cg07339236 & ATP9A & 0.23 & 0.18 & -0.05 & $<0.001$ & -0.37 \\
\hline $\operatorname{cg} 14817490$ & AHRR & 0.32 & 0.26 & -0.07 & $<0.001$ & -0.33 \\
\hline $\operatorname{cg} 17246140$ & HAAO & 0.22 & 0.17 & -0.05 & $<0.001$ & -0.34 \\
\hline $\operatorname{cg} 05951221$ & & 0.43 & 0.34 & -0.08 & $<0.001$ & -0.31 \\
\hline $\operatorname{cg} 26827373$ & ZNF844 & 0.27 & 0.22 & -0.05 & $<0.001$ & -0.28 \\
\hline $\operatorname{cg} 03636183$ & F2RL3 & 0.69 & 0.58 & -0.12 & $<0.001$ & -0.26 \\
\hline cg07381806 & MOB3A & 0.48 & 0.41 & -0.07 & $<0.001$ & -0.23 \\
\hline $\operatorname{cg} 25189904$ & GNG12 & 0.48 & 0.41 & -0.07 & $<0.001$ & -0.23 \\
\hline $\operatorname{cg} 23161492$ & ANPEP & 0.38 & 0.32 & -0.05 & $<0.001$ & -0.22 \\
\hline $\operatorname{cg} 13184736$ & GNG12 & 0.44 & 0.38 & -0.05 & $<0.001$ & -0.19 \\
\hline $\operatorname{cg} 06126421$ & & 0.74 & 0.65 & -0.09 & $<0.001$ & -0.19 \\
\hline $\operatorname{cg} 21140898$ & & 0.38 & 0.33 & -0.05 & $<0.001$ & -0.19 \\
\hline $\operatorname{cg} 01940273$ & & 0.60 & 0.53 & -0.07 & $<0.001$ & -0.18 \\
\hline $\operatorname{cg} 19717773$ & GNA12 & 0.72 & 0.65 & -0.07 & $<0.001$ & -0.16 \\
\hline $\operatorname{cg} 01208318$ & & 0.52 & 0.48 & -0.05 & $<0.001$ & -0.14 \\
\hline cg05329352 & ADRA2A & 0.61 & 0.55 & -0.06 & $<0.001$ & -0.14 \\
\hline $\operatorname{cg} 19572487$ & RARA & 0.55 & 0.50 & -0.05 & $<0.001$ & -0.14 \\
\hline $\operatorname{cg} 26889659$ & EXOC2 & 0.77 & 0.70 & -0.07 & $<0.001$ & -0.13 \\
\hline $\operatorname{cg} 18446336$ & GNA12 & 0.58 & 0.52 & -0.05 & $<0.001$ & -0.14 \\
\hline $\operatorname{cg} 20698421$ & SLC1A4 & 0.61 & 0.56 & -0.05 & $<0.001$ & -0.13 \\
\hline $\operatorname{cg} 21161138$ & AHRR & 0.70 & 0.64 & -0.06 & $<0.001$ & -0.12 \\
\hline $\operatorname{cg} 16836311$ & MAN1C1 & 0.64 & 0.59 & -0.05 & $<0.001$ & -0.12 \\
\hline $\operatorname{cg} 09069072$ & TMEM51 & 0.81 & 0.75 & -0.06 & $<0.001$ & -0.11 \\
\hline cg03991871 & AHRR & 0.84 & 0.78 & -0.06 & $<0.001$ & -0.11 \\
\hline $\operatorname{cg} 09935388$ & GFI1 & 0.77 & 0.72 & -0.05 & $<0.001$ & -0.10 \\
\hline $\operatorname{cg} 26361535$ & ZC3H3 & 0.74 & 0.69 & -0.05 & $<0.001$ & -0.10 \\
\hline $\operatorname{cg} 25648203$ & AHRR & 0.76 & 0.72 & -0.05 & $<0.001$ & -0.09 \\
\hline $\operatorname{cg} 12803068$ & MYO1G & 0.76 & 0.82 & 0.06 & $<0.001$ & 0.12 \\
\hline $\operatorname{cg} 19758448$ & PGAP3 & 0.53 & 0.58 & 0.05 & $<0.001$ & 0.12 \\
\hline $\operatorname{cg} 05059607$ & PITPNC1 & 0.45 & 0.49 & 0.05 & $<0.001$ & 0.14 \\
\hline $\operatorname{cg} 08035323$ & & 0.30 & 0.35 & 0.05 & $<0.001$ & 0.21 \\
\hline $\operatorname{cg} 12423733$ & MAS1L & 0.23 & 0.28 & 0.05 & $<0.001$ & 0.26 \\
\hline
\end{tabular}

${ }^{\mathrm{a}} \log _{2}$ ( $\beta$ value of smokers $/ \beta$ value of non-smokers) 
under-methylated in smokers. These studies included participants from the KORA S4 survey, African American females from the states of Iowa and Georgia, and general population-based epidemiological ESTHER study participants (Zeilinger et al. 2013; Dogan et al. 2014; Breitling et al. 2011). The combined data revealed that the DNA methylation patterns of 8 CpG sites $(\operatorname{cg} 05575921, \operatorname{cg} 21161138$, and cg26703534 in AHRR, cg01940273, cg06126421, cg21566642, cg03636183 in $F 2 R L 3$, and $\operatorname{cg} 19572487$ in RARA) might change depending on the smoking status, regardless of race. In addition, we identified that rs951295, cg00587941, $\operatorname{cg} 11314779$, and $\operatorname{cg} 02126896$ were under- or over-methylated by $\geq 15 \%$ in smokers. These results indicate that methylation of these $4 \mathrm{CpG}$ sites may be new candidate indicators for long-term smoking exposure. The biological implications of methylation changes at rs951295 (within RNA gene LOC105370802), cg00587941, and $\operatorname{cg} 02126896$ remain unknown. The $\operatorname{cg} 11314779$ site is located in the intron of CELF6. Since the CELF6 is associated with addiction (Bryant and Yazdani 2016), it may be interesting to study the relationship between methylation of $\operatorname{cg} 11314779$ and addiction.

Smoking is the main source of cadmium exposure. The blood cadmium concentrations of smokers were found to be significantly higher than those of non-smokers in this study. We identified cadmium exposure-related DNA methylation of 307 CpG sites (including 207 unique genes). CCL22, a signal transduction-related gene, was differentially methylated by cadmium exposure. A previous study on the relationship between cadmium exposure and CCL22 was retrieved from the PubMed database (February 17, 2020). The mRNA level of CCL22 decreased in antigen-activated lymphocytes due to cadmium treatment (Ebaid et al. 2014). Further studies are needed to determine whether DNA methylation of CCL22 due to cadmium exposure affects the gene expression. $\operatorname{cg} 05575921$ and $\operatorname{cg} 23576855$ in AHRR, $\operatorname{cg} 03636183$ in $F 2 R L 3$, and $\operatorname{cg} 21566642$ that have not been previously reported to be associated with cadmium exposure were included in our study. These were under-methylated by $>10 \%$ in smokers compared to that in non-smokers. DNA methylation of $\operatorname{cg} 05575921$ in AHRR (Beach et al. 2015) and cg03636183 in F2RL3 (Zeilinger et al. 2013; Breitling et al. 2011) is the putative indicator for smoking. Taken together, these CpG sites (cg05575921 and cg23576855 in AHRR, $\operatorname{cg} 03636183$ in $F 2 R L 3$, and $\operatorname{cg} 21566642$ ) may be differentially methylated by cadmium exposure due to smoking.

The Gene Ontology terms were analyzed to identify the biological functions of genes differentially methylated due to smoking and cadmium exposure. Among the 70 genes found to be differentially methylated in smokers compared to nonsmokers, HOPX (cg25456368), RARG (cg20059012), and ZFP57 (cg12463578) genes, found to be under-methylated in the non-promoter regions, are involved in negative transcription regulation. Previous studies have reported that hyper-methylation in non-promoter regions of $M M P 9$ (Falzone et al. 2016) and CDKN2A (Ben-Dayan et al. 2017) was associated with transcriptional activation. Therefore, the expression of $H O P X, R A R G$, and ZFP57 genes might also be regulated by DNA methylation in the non-promoter regions. Glandular epithelial cell development $(R A R A)$, negative regulation of transcription from RNA polymerase II promoter $(A H R R)$, and regulation of myelination $(R A R A)$ are the biological functions 
of some genes that were differentially methylated by both smoking and cadmium exposure. The RARA gene acts as retinoic acid receptor, nuclear receptor, and steroid hormone receptor (Tsaprouni et al. 2014). Recently, it has been reported that differential DNA methylation in RARA is associated with smoking in African Americans (Barcelona et al. 2019). Our data showed that $\operatorname{cg} 19572487$ in RARA was under-methylated by $9 \%(\Delta \beta$-value $=-0.05)$ in smokers compared to that in non-smokers (data not shown). Thus, alterations to DNA methylation in RARA can be caused by cadmium exposure as well as smoking.

The urinary cotinine level is a sensitive biomarker for tobacco smoking (Kulza et al. 2012; Raja et al. 2016) Behera et al. (2003). showed that mean urinary cotinine levels were $2736.20 \pm 983.29 \mathrm{ng} / \mathrm{mL}$ and $7.30 \pm 2.47 \mathrm{ng} / \mathrm{mL}$ in smokers and non-smokers, respectively. Sharma et al. (2019) reported that mean urinary cotinine levels were $1043.69 \pm 1514.01 \mathrm{ng} / \mathrm{mL}$ and $13.60 \pm 12.73 \mathrm{ng} / \mathrm{mL}$ in smokers and non-smokers, respectively. Our study found that smokers had a mean urinary cotinine concentration of $1847.95 \pm 1178.87 \mathrm{ng} / \mathrm{mL}$ and non-smokers had a mean of $12.22 \pm 17.16 \mathrm{ng} / \mathrm{mL}$. Thus, these findings suggest that urinary cotinine values may be an indicator for smoking.

In conclusion, our study showed that $136 \mathrm{CpG}$ sites (including 70 unique genes) were differentially methylated by smoking. Among these, DNA methylation levels of rs951295, cg00587941, cg11314779, and cg02126896 sites may be new putative indicators for smoking intensity. Furthermore, DNA methylation at cg05575921 and cg23576855 in AHRR, cg03636183 in F2RL3, and $\operatorname{cg} 21566642$ may be altered by smoking-induced cadmium exposure. These findings provide a novel insight into smoking-induced genetic alterations that might be involved in associated diseases.

Acknowledgements This work was supported by the Korea National Institute of Health, Korea Centers for Disease Control and Prevention (Grant No. 4800-4845-301, Project No. 213-03CON-04-P, 2014-03EXP-03-1C-A).

\section{Compliance with Ethical Standards}

Conflict of interest All authors declare that they have no conflict of interest.

Ethics Approval All procedures performed in studies involving human participants were in accordance with the ethical standards of the Institutional Review Board (IRB) of the Korea Centers for Disease Control and Prevention (IRB No. 213-03CON-04-P, 2014-03EXP-03-1C-A) and with the 1964 Helsinki declaration and its later amendments or comparable ethical standards.

Open Access This article is licensed under a Creative Commons Attribution 4.0 International License, which permits use, sharing, adaptation, distribution and reproduction in any medium or format, as long as you give appropriate credit to the original author(s) and the source, provide a link to the Creative Commons licence, and indicate if changes were made. The images or other third party material in this article are included in the article's Creative Commons licence, unless indicated otherwise in a credit line to the material. If material is not included in the article's Creative Commons licence and your intended use is not permitted by statutory regulation or exceeds the permitted use, you will need to obtain permission directly from the copyright holder. To view a copy of this licence, visit http://creativecommons.org/licen ses/by/4.0/. 


\section{References}

Barcelona V, Huang Y, Brown K, Liu J, Zhao W, Yu M, Kardia SLR, Smith JA, Taylor JY, Sun YV (2019) Novel DNA methylation sites associated with cigarette smoking among African Americans. Epigenetics 14(4):383-391

Batariova A, Spevackova V, Benes B, Cejchanova M, Smid J, Cerna M (2006) Blood and urine levels of $\mathrm{Pb}, \mathrm{Cd}$ and $\mathrm{Hg}$ in the general population of the Czech Republic and proposed reference values. Int $\mathrm{J}$ Hyg Environ Health 209:359-366

Beach SR, Gerrard M, Gibbons FX, Brody GH, Philibert RA (2015) A role for epigenetics in broadening the scope of pediatric care in the prevention of adolescent smoking. Epigenet Diagn Ther 1:91-97

Behera D, Uppal R, Majumdar S (2003) Urinary levels of nicotine \& cotinine in tobacco users. Indian J Med Res 118:129-133

Ben-Dayan MM, Ow TJ, Belbin TJ, Wetzler J, Smith RV, Childs G, Diergaarde B, Hayes DN, Grandis JR, Prystowsky MB, Schlecht NF (2017) Nonpromoter methylation of the CDKN2A gene with active transcription is associated with improved locoregional control in laryngeal squamous cell carcinoma. Cancer Med 6:397-407

Breitling LP, Yang R, Korn B, Burwinkel B, Brenner H (2011) Tobacco-smoking-related differential DNA methylation: 27K discovery and replication. Am J Hum Genet 88:450-457

Bryant CD, Yazdani N (2016) RNA-binding proteins, neural development and the addictions. Genes Brain Behav 15(1):169-186

Centers for Disease Control and Prevention (CDC) (2008) Smoking-attributable mortality, years of potential life lost, and productivity losses-United States 2000-2004. MMWR Morb Mortal Wkly Rep 57:1226-1228

Cheng L, Liu J, Li B, Liu S, Li X, Tu H (2016) Cigarette smoke-induced hypermethylation of the GCLC gene is associated with COPD. Chest 149:474-482

Dogan MV, Shields B, Cutrona C, Gao L, Gibbons FX, Simons R, Monick M, Brody GH, Tan K, Beach SR, Philibert RA (2014) The effect of smoking on DNA methylation of peripheral blood mononuclear cells from African American women. BMC Genomics 15:151

Ebaid H, Hassan I, Bashandy S, Taha NA, Mahmood A, Alomar S, Alhazza I, Mashaly A, Rady A (2014) Zinc improves the immune function and the proliferation of lymphocytes in Cadmium-treated rats. Cent Eur J Immunol 39(4):441-448

El-Agha O, Gokmen IG (2002) Smoking habits and cadmium intake in Turkey. Biol Trace Elem Res 88:31-43

Elinder CG, Kjellstrom T, Lind B, Linnman L, Piscator M, Sundstedt K (1983) Cadmium exposure from smoking cigarettes: variations with time and country where purchased. Environ Res 32:220-227

Fairley TL, Tai E, Townsend JS, Stewart SL, Steele CB, Davis SP, Underwood JM (2010) Racial/Ethnic disparities and geographic differences in lung cancer incidence-38 States and the District of Columbia, 1998-2006. MMWR Morb Mortal Wkly Rep 59:1433-1438

Falzone L, Salemi R, Travali S, Scalisi A, McCubrey JA, Candido S, Libra M (2016) MMP-9 overexpression is associated with intragenic hypermethylation of MMP9 gene in melanoma. Aging (Albany NY) 8:933-944

Jarup L, Akesson A (2009) Current status of cadmium as an environmental health problem. Toxicol Appl Pharmacol 238:201-208

Jones PA (2012) Functions of DNA methylation: islands, start sites, gene bodies and beyond. Nat Rev Genet 13:484-492

Kulza M, Wozniak A, Przybyłowska SM, Czarnywojtek A, Kurhanska-Flisykowska A, Florek E (2012) Saliva cotinine determination using high-performance liquid chromatography with diode-array detection. Przegl Lek 69(10):837-840

Larsson SC, Wolk A (2016) Urinary cadmium and mortality from all causes, cancer and cardiovascular disease in the general population: systematic review and meta-analysis of cohort studies. Int J Epidemiol 45:782-791

Lee DH, Hwang SH, Lim MK, Oh JK, Song DY, Yun EH, Park EY (2017) Performance of urine cotinine and hypomethylation of AHRR and F2RL3 as biomarkers for smoking exposure in a populationbased cohort. PLoS ONE 12:e0176783

Ma Y, Li MD (2017) Establishment of a strong link between smoking and cancer pathogenesis through DNA methylation analysis. Sci Rep 7:1811 
Mathers CD, Loncar D (2006) Projections of global mortality and burden of disease from 2002 to 2030. PLoS Med 3:e442

Mokdad AH, Marks JS, Stroup DF, Gerberding JL (2004) Actual causes of death in the United States, 2000. JAMA 291:1238-1245

Morrow JD, Cho MH, Hersh CP, Pinto-Plata V, Celli B, Marchetti N, Criner G, Bueno R, Washko G, Glass K, Choi AMK, Quackenbush J, Silverman EK, DeMeo DL (2016) DNA methylation profiling in human lung tissue identifies genes associated with COPD. Epigenetics 11:730-739

Mortensen ME, Wong LY, Osterloh JD (2011) Smoking status and urine cadmium above levels associated with subclinical renal effects in U.S. adults without chronic kidney disease. Int J Hyg Environ Health 214:305-310

Nordberg M, Jin T, Nordberg GF (1992) Cadmium, metallothionein and renal tubular toxicity. IARC Sci Publ 118:293-297

Raja M, Garg A, Yadav P, Jha K, Handa S (2016) Diagnostic methods for detection of cotinine level in tobacco users: a review. J Clin Diagn Res 10(3):ZE04-06

Selamat SA, Chung BS, Girard L, Zhang W, Zhang Y, Campan M, Siegmund KD, Koss MN, Hagen JA, Lam WL, Lam S, Gazdar AF, Laird-Offringa IA (2012) Genome-scale analysis of DNA methylation in lung adenocarcinoma and integration with mRNA expression. Genome Res 22:1197-1211

Sundar IK, Mullapudi N, Yao H, Spivack SD, Rahman I (2011) Lung cancer and its association with chronic obstructive pulmonary disease: update on nexus of epigenetics. Curr Opin Pulm Med 17:279-285

Sundar IK, Yao H, Rahman I (2013) Oxidative stress and chromatin remodeling in chronic obstructive pulmonary disease and smoking-related diseases. Antioxid Redox Signal 18:1956-1971

Sundar IK, Yin Q, Baier BS, Yan L, Mazur W, Li D, Susiarjo M, Rahman I (2017) DNA methylation profiling in peripheral lung tissues of smokers and patients with COPD. Clin Epigenet 9:38

Thun MJ, DeLancey JO, Center MM, Jemal A, Ward EM (2010) The global burden of cancer: priorities for prevention. Carcinogenesis 31:100-110

Tsaprouni LG, Yang TP, Bell J, Dick KJ, Kanoni S, Nisbet J, Vinuela A, Grundberg E, Nelson CP, Meduri E, Buil A, Cambien F, Hengstenberg C, Erdmann J, Schunkert H, Goodall AH, Ouwehand WH, Dermitzakis E, Spector TD, Samani NJ, Deloukas P (2014) Cigarette smoking reduces DNA methylation levels at multiple genomic loci but the effect is partially reversible upon cessation. Epigenetics 9(10):1382-1396

Sharma P, Sane N, Anand SD, Marimutthu P, Benegal V (2019) Assessment of cotinine in urine and saliva of smokers, passive smokers, and nonsmokers: Method validation using liquid chromatography and mass spectrometry. Indian J Psychiatry 61:270-276

Vineis P, Alavanja M, Buffler P, Fontham E, Franceschi S, Gao YT, Gupta PC, Hackshaw A, Matos E, Samet J, Sitas F, Smith J, Stayner L, Straif K, Thun MJ, Wichmann HE, Wu AH, Zaridze D, Peto R, Doll R (2004) Tobacco and cancer: recent epidemiological evidence. J Natl Cancer Inst 96:99-106

Virani S, Rentschler KM, Nishijo M, Ruangyuttikarn W, Swaddiwudhipong W, Basu N, Rozek LS (2016) DNA methylation is differentially associated with environmental cadmium exposure based on sex and smoking status. Chemosphere 145:284-290

World Health Organization (WHO) (2014) WHO Tobacco fact sheet N339. http://www. Who.int/media centre/factsheets/fs339/en/.

Yang IV, Schwartz DA (2011) Epigenetic control of gene expression in the lung. Am J Respir Crit Care Med 183:1295-1301

Yao H, Rahman I (2011) Current concepts on oxidative/carbonyl stress, inflammation and epigenetics in pathogenesis of chronic obstructive pulmonary disease. Toxicol Appl Pharmacol 254:72-85

Zeilinger S, Kuhnel B, Klopp N, Baurecht H, Kleinschmidt A, Gieger C, Weidinger S, Lattka E, Adamski J, Peters A, Strauch K, Waldenberger M, Illig T (2013) Tobacco smoking leads to extensive genome-wide changes in DNA methylation. PLoS ONE 8:e63812

Publisher's Note Springer Nature remains neutral with regard to jurisdictional claims in published maps and institutional affiliations. 